\title{
Some Physio-Chemical Properties of Silybummarianum Seed Oil Extract
}

\author{
Faiza Anum, Naveed Iqbal Raja, Noor-Ul-Ain, Uneeza Javed and Farhat Yasmeen* \\ Department of Botany, PMAS Arid Agriculture University Rawalpindi, Pakistan
}

Submission: December 07, 2017; Published: April 13, 2018

*Corresponding author: Farhat Yasmeen, Department of Botany, PMAS Arid Agriculture University Rawalpindi, Pakistan,

Email: fyasmeen.1315@gmail.com

\section{Abstract}

Silybummarianum seed extract have promising effects in nutrition as well as in therapeutics. Therefore, present study was designed to evaluate composition and physio-chemical effects of Silybummarianum seed oil in PMAS-AAUR, Rawalpindi Pakistan. Proximate seed analysis of Silybummarianum indicated the increase in dry matter (15.75\%),crude fiber (14.4\%) whereas moisture (8.2\%), crude protein (15.75\%), crude fat $(24 \%)$ total ash $(4 \%)$ did not proved to significant increase in present study. In case of physico-chemical parameters saponification value $(126.2 \mathrm{mg} \mathrm{KOH} / \mathrm{g})$ and ester value $(121.15 \mathrm{mg} / \mathrm{g})$ were increased while peroxide $(7.056 \mathrm{meq}$. Peroxide/g), free fatty acid $(2.53 \mathrm{mg} / \mathrm{g})$, iodine $(2.79 \mathrm{mg} / \mathrm{g})$, acid $(5.049 \mathrm{mg} \mathrm{KOH} / \mathrm{g})$, wax $(6.89 \mathrm{mg} / \mathrm{g}) \mathrm{pH}$ is 8.09 and specific gravity $(0.8129)$ have lower values. High in saponification and low acid values make this oil suitable for soap industry also increases quality and volatility of oil. Low Peroxide value shows its low oxidation, rancidity and high antioxidant activity.

\section{Introduction}

Silybummarianum (Milk thistle) belongs to the family Asteraceae. It is well known since the time of "Theophrastus" and "Dioscorides" [1]. It is native to the North Africa and Mediterranean area and found as annuals or biennials [2,3]. Silybum species are highly medicinal and contributes a lot to ethnomedicine [4-6]. It is highly tolerant to drought conditions $[4,7]$.

Milk thistle can also be cultivated for several purposes [8]. Because of its attractive, beautiful spiny and creamy foliage it is cultivated ornamentally [9]. Its stems, roasted seeds and inflorescence are consumed either raw as well as cooked [10]. In Silybummarianum flowering continue throughout the whole life cycle [11]. So it is a major problem for selecting harvesting period of Silybummarianum [12].

Seeds are common and traditional sources of oil. With increasing demand of better quality oils, Milk thistle seeds oil is cheap, healthy and beneficial for human consumption [13], having no side effects $[14,15]$. These seeds oils are rich in flavonoids, amines, trace elements, vitamins and some other factors [16]. Its seeds oil contain relatively high amount of unsaturated fatty acids principally (21-36 percent) oleic acid and (42-54 percent) linoleic acid [2,17-20]. It was reported that under drought condition oil content decreases by 4 percent while a significant increase was observed in polyunsaturated fatty acids [17].

Silymarin is a major component of seeds extract of milk thistle and it is a polyphenolic healthy component with highly medicinal properties [21]. "Silybin" is the main component of silymarin containing 30 percent calcium and is extracted from fruit of milk thistle $[22,23]$. It is hepatoprotective and used for the treatment of liver disorders [14,15,24-27]. Silymarin is recognized as antioxidant, anticancer. Anti-metastasis, antiinflammatory $[9,28-30]$ and also enhances the immunity against hepatitis C [21]. Silymarin prevents infiltration of neutrophils and control spread of inflammatory agents [31].

Compounds derived from Silybummarianum seed extract are found to have a promising effect in nutrition as well as in therapeutics. Previous studies on S. marianum focus on proximate analysis, physiochmical parameters and its medicinal uses. Therefore, present study was designed to check and compare the proximate values like moisture, protein, dry matter, total ash, protein, fat and crude fiber content, Physiochemical parameters such as saponification, peroxide, free fatty acid, specific gravity, ester, $\mathrm{pH}$, wax content, acid and iodine value and anti-oxidant activity of oil to promote its importance in pharmaceutical and good industry.

\section{Materials and Methods}

\section{Sample collection and preparation}

Silybummarianum seeds were collected from the fields of PirMeher Ali Shah Arid Agriculture University, Rawalpindi. These seeds were sterilized under sun light. After that the sample was grounded into powered form with the help of laboratory grinder. For further analysis, the sample was kept in fine plastic bags and stored in refrigerator at $4{ }^{\circ} \mathrm{C}$. 


\section{Extraction of oil}

The seed powder was weighed and $12 \mathrm{~g}$ sample was placed in extraction thimble filter paper. The thimble was kept in loading chamber and extracted with $125 \mathrm{ml}$ of $\mathrm{n}$-hexane that was kept in the $250 \mathrm{ml}$ reflux flask, for about $6 \mathrm{~h}$ in soxhlet apparatus. The change in color was observed when oil is transferred into the solvent [32], the solvent was separated after extraction by soxhlet apparatus using a vacuum evaporator at $45{ }^{\circ} \mathrm{C}$. The remaining $n$-hexane was allowed to evaporate by allowing the extract to stand at room temperature for $24 \mathrm{~h}$. The remaining extract was weighed to determine the amount of oil from $12 \mathrm{~g}$ of seeds. This process was repeated for three times and oil was stored at $4{ }^{\circ} \mathrm{C}$ for further analysis.

\section{Proximate Analysis of Silybummarianum}

Moisture, dry matter, total ash, protein and fat contents were determined by standard AOAC, 1990 method. Whereas crude fiber content was determined by the standard method of Duke and Atchley (1984) and results showed in percentage. Moisture and dry matter content both were calculated separately by the following formula;

W1-W x 10/ Sample weight ${ }_{3}$

$\left(\mathrm{W}_{1}=\right.$ weight of empty Petri dish, $\mathrm{W}_{2}=$ weight of empty Petri dish + wet weight, $\mathrm{W}_{3}=$ weight of empty Petri dish + dry weight)

Total ash value was calculated by following formula;

A-B $\times 100 / C$ ( $A=$ weight of crucible with sample, $B=$ weight of crucible with ash, $\mathrm{C}=$ weight of sample)

Protein and fat content was determined by using following formulas.

Protein content $=\left(\mathrm{V}_{1}-\mathrm{V}_{2}\right) \mathrm{N} \times 14 \times 25 \times 100 / \mathrm{W}$

$\left(\mathrm{V}_{1}=\right.$ volume of plant sample in $\mathrm{ml}, \mathrm{V}_{2}=$ volume of blank in $\mathrm{ml}$, $\mathrm{N}=$ Normality of standardized $\mathrm{H}_{2} \mathrm{SO}_{4}, \mathrm{~W}=$ weight of sample)

Fat content=Initial weight - Final weight $\times 100$ / initial weight

\section{Determination of physiochemical parameters}

Determination of the saponification value (Protocol reference): Oil sample of $2 \mathrm{~g}$ was poured in conical flask. $30 \mathrm{ml}$ of $0.5 \mathrm{M}$ alcoholic potassium hydroxide $(\mathrm{KOH})$ was added, weighed and heated for 30 mints to ensure that sample will be fully dissolved. One milliliter 1 percent phenolphthalein indicator was added. Out of this solution $1 \mathrm{ml}$ was taken and introduced into hot mixture of reaction. This solution was titrated with $0.5 \mathrm{ml}$ hydrochloric acid (HCL) until it become color less, a blank titration was also done side by side which was the measurement of volume of HCL which was used to neutralize the blank. For sake of accuracy, the process was repeated three times to get saponification value of oil by following formula:

$$
\mathrm{SV}=\mathrm{Vb}-\mathrm{Vs} \times 28 / \mathrm{W}
$$

Determination of peroxide value (Protocol reference): Take $6 \mathrm{~g}$ of sample, $20 \mathrm{ml}$ of chloroform, $30 \mathrm{ml}$ of glacial acetic acid and $2 \mathrm{ml}$ of freshly prepared saturated aqueous solution of potassium iodide were added into flask. The flask will be shaken consistently in the dark for 5 mints then $150 \mathrm{ml}$ of distilled

Water was added. This mixture was mixed thoroughly. $10 \mathrm{ml}$ of this mixture was poured in separate flask and $2 \mathrm{ml}$ of one percent soluble starch solution was introduced as indicator. After the addition mixture was titrated by using sodium thiosulphate solution of 0.02 molarities. A reagent blank determined was used. The following formula was use to determined peroxide value.

Peroxide value $=126\left(\mathrm{~V}_{\mathrm{b}}-\mathrm{V}_{\mathrm{s}}\right) \times 10 / \mathrm{W}$

Determination of free fatty acids: The contents of free fatty acids present in oil was found by using AOAC [33] method. $3.5 \mathrm{~g}$ of the oil is poured in a clean dry flask containing $225 \mathrm{ml}$ neutralized alcohol. The resultant mixture was titrated against $0.25 \mathrm{~N}$ solution of $\mathrm{NaOH}$ until a faint pink color appeared. A blank titration was carried out to estimate the volume used to titrate the blank volume of the $0.25 \mathrm{~N} \mathrm{NaOH}$ used was note. The percentage of free fatty acids was determined by using the formula given below:

\section{Percentage of free fatty acids $=\left(V_{b}-V_{7 s}\right) \times N \times 28.2 / \mathrm{W}$}

Determination of specific gravity (Protocol reference): Oil specific gravity was determined through specific gravity bottle. Gravity bottle of $50 \mathrm{ml}$ was filled up to the mark and weighed before and after insertion of stopper. Now the bottle was dried and again filled up to the mark with oil, stopper was inserted and bottle was weighed. The oil specific gravity was determined using the formula:

Specific gravity $=\mathrm{W}$ oil $-\mathrm{W}$ bottle $/ \mathrm{W}$ water $-\mathrm{W}$ bottle

Density of oil was determined by multiplying the specific gravity of oil with density of water.

Determination of ester value (Protocol reference): Ester value was determined from saponification value and acid value by using the following formula

Ester value=saponification number - acidity index

Determination of pH of oil (Protocol reference): Oil sample was mix with $10 \mathrm{ml}$ of warm distilled water and place this solution into the cool water bath to decrease its temperature to $25{ }^{\circ} \mathrm{C}$. $\mathrm{pH}$ of this solution was measured by using $\mathrm{pH}$ meter.

Determination of wax content of oil: Wax contents of the oil were determined by [34]. $5 \mathrm{~g}$ of oil and $25 \mathrm{ml}$ of acetone were added in flask then placed in freezer for $24 \mathrm{~h}$ at $4{ }^{\circ} \mathrm{C}$ to crystal the wax. The insoluble part of the solution (acetone) was filtered by using pre-weighed What man No.1 filter paper. Filter paper was dried in vacuum oven at $45{ }^{\circ} \mathrm{C}$ and weighed to obtain the wax contents.

Acid Value: Sample of $1 \mathrm{~g}$ was dissolved with $50 \mathrm{ml}$ of ethanol in conical flask. Two drops of Phenolphthalein were used as indicator and titrated it with $0.1 \mathrm{~N}$ potassium hydroxide solution 
$(\mathrm{KOH})$ to pink end point. Acid value was calculated by using following formula [35].

$$
\text { Acid value }=56.1 \times \mathrm{V} \times \mathrm{C} / \mathrm{M}
$$

(56.1=Equivalent weight of $\mathrm{KOH}, \mathrm{V}=$ Volume in $\mathrm{ml}$ of standard volumetric $\mathrm{KOH}$ solution used, $\mathrm{C}=$ Concentration in $\mathrm{KOH}$ solution used $(0.1 \mathrm{~N}), \mathrm{M}=$ Mass of sample)

Determination of iodine value of oil (Protocol reference): Oil sample of $0.25 \mathrm{~g}$ along with $10 \mathrm{ml}$ of chloroform were added in flask then $30 \mathrm{ml}$ of Hanus solution was added and closed the flask by Aluminum foil then left it for 30 minutes with continuous shaking. Added $10 \mathrm{ml}$ of $15 \%$ of Potassium Iodide (KI) and $100 \mathrm{ml}$ of distilled water. Titrated the iodine solution against $0.1 \mathrm{~N}$ of Sodium thiosulphate $\left(\mathrm{Na}_{2} \mathrm{~S}_{2} \mathrm{O}_{3}\right)$ till yellow color appeared, then added two to three drops of starch solution and blue color was appeared, then continued titration till blue color disappeared. Iodine value was calculated by using following formula.

$$
\text { Iodine Value }=\left(\mathrm{V}_{\mathrm{b}}-\mathrm{V}_{\mathrm{s}}\right) \times \mathrm{N} \text { of Na2S2O3 } \times 127 \mathrm{~g} / \mathrm{meq} \times 10 / \mathrm{W}
$$

$\left(\mathrm{V}_{\mathrm{b}}=\right.$ Volume of blank, $\mathrm{V}_{\mathrm{s}}=$ Volume of sample, $\mathrm{N}=$ Normality of

\section{Results}

\section{Proximate analysis}

Sodium thiosulphate, $127=$ Mass equivalent of Iodine, $\mathrm{W}=$ Weight of sample)

\section{Antioxidant activity}

Antioxidant properties of Silybummarianumu seed oil was determined by reducing power assay. This assay was described by Chung [36]. In this assay different dilutions were prepared from Silybummarianum seed oil. $2 \mathrm{ml}$ of each dilution was mixwith $2 \mathrm{ml}$ of potassium ferricynide $(1 \mathrm{mg} / \mathrm{ml})$ and $2 \mathrm{ml}$ of $0.2 \mathrm{M}$ of phosphate buffer (pH 6.6) in test tube. Incubated it at $50{ }^{\circ} \mathrm{C}$ for 20 minutes and then cooled it. Added $2 \mathrm{ml}$ of tris acetic acid (1\%), the mixture was then centrifuged at $3000 \mathrm{~g}$ for 10 minutes. The supernatant $(0.25 \mathrm{ml})$ was mixed with $0.25 \mathrm{ml}$ distilled water and $0.1 \% \mathrm{FeCl} 3(0.5 \mathrm{ml})$ and left it for $10 \mathrm{~min}$. Measured its absorbance at $700 \mathrm{~nm}$. Increased absorbance by reaction mixture showed the higher antioxidant activity.

\section{Statistical analysis}

Analysis of each parameter was carried out by using the mean and standard deviation.

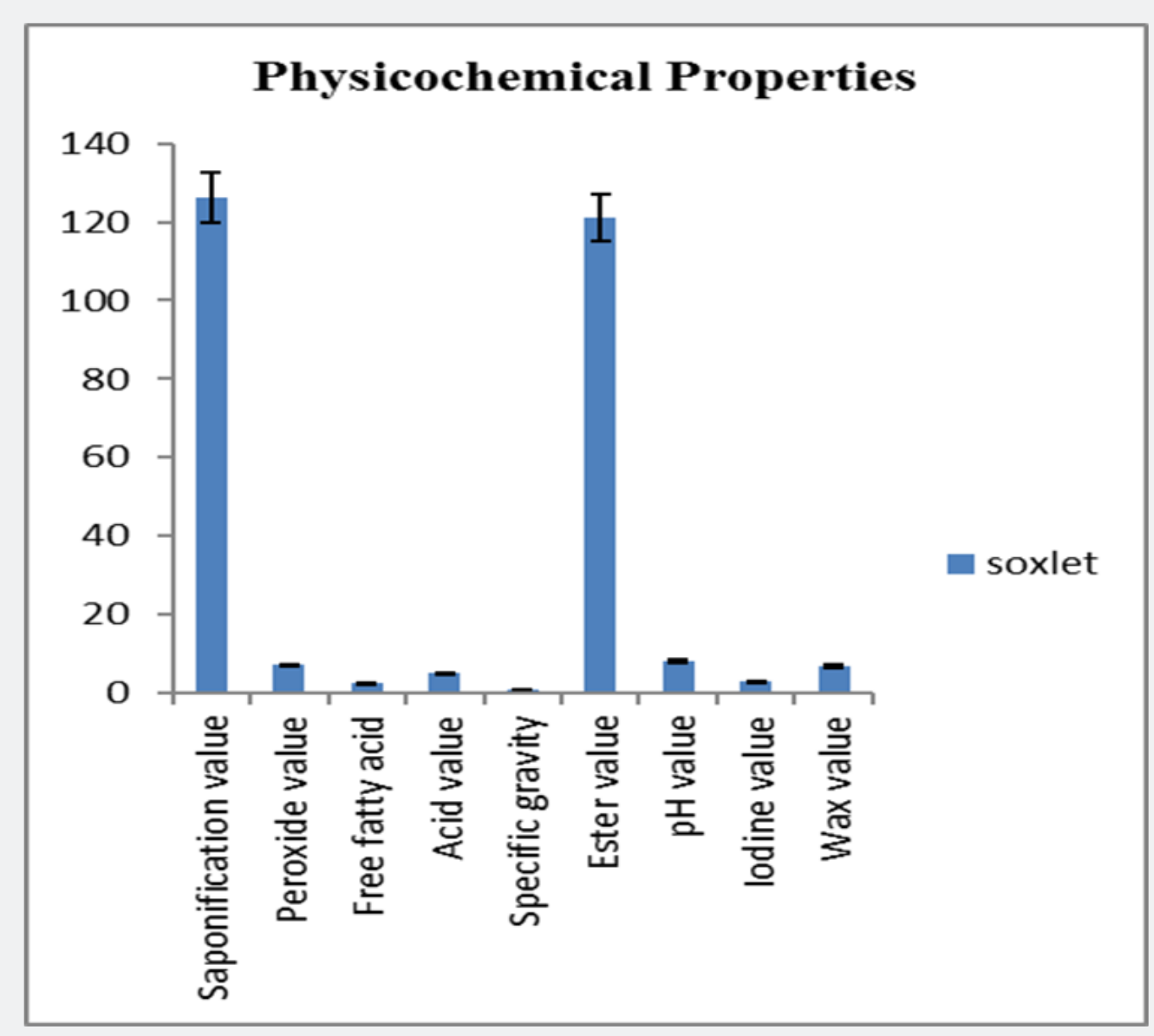

Figure 1 
Proximate analysis of Silybummarianum is shown in the Figures 1. Results of analysis showed that Silybummarianum has maximum content of dry matter (91.8\%) and crude fiber (24 $\%)$. A significant amount of protein (15.75\%) was also found. Total ash (4\%) was found in the lowest amount. Crude fat were $14.4 \%$ and moisture content was found to be $8.2 \%$. Proximate analysis of Silybummarianum seed is shown in Table 1.

Table 1: Proximate analysis of Silybummarianum seeds.

\begin{tabular}{|c|c|}
\hline Proximate Analysis (\%) & Values \\
\hline Moisture content & $8.2 \pm 0.52$ \\
\hline Dry matter content & $91.8 \pm 0.52$ \\
\hline Ash value & $4 \pm 0.40$ \\
\hline Crude Protein & $15.75 \pm 0.52$ \\
\hline Crude Fat & $14.4 \pm 0.50$ \\
\hline Crude Fiber & $24 \pm 0.36$ \\
\hline
\end{tabular}

Each value represents the average of three replicate analysis \pm S.D

\section{Physicochemical parameters}

Result of the analysis shows that Silybummarianum has peroxide value $(7.056 \mathrm{meq}$. Peroxide/g), saponification value (126.2mg KOH/g), ester value $(121.15 \mathrm{mg} / \mathrm{g})$, free fatty acid $(2.53 \mathrm{mg} / \mathrm{g})$, iodine value $(2.79 \mathrm{mg} / \mathrm{g})$, Acid value is $5.049 \mathrm{mg}$ $\mathrm{KOH} / \mathrm{g}$, wax value is $6.89 \mathrm{mg} / \mathrm{g}, \mathrm{pH}$ is 8.09 and specific gravity is 0.8129 . Results of physicochemical properties are shown in Table 2 and in Figure 1.

Table 2: Physicochemical properties of Silybummarianum seed oil.

\begin{tabular}{|c|c|}
\hline Physicochemical Property & Values \\
\hline Saponification value & $126.2 \pm 0.46$ \\
\hline Peroxidase value & $7.05 \pm 0.05$ \\
\hline Free fatty Acid & $2.53 \pm 0.03$ \\
\hline Acid value & $5.04 \pm 0.27$ \\
\hline Specific gravity & $0.81 \pm 0.01$ \\
\hline Ester value & $121.15 \pm 0.53$ \\
\hline pH value & $8.09 \pm 0.10$ \\
\hline Iodine value & $2.79 \pm 0.11$ \\
\hline Wax value & $6.89 \pm 0.10$ \\
\hline
\end{tabular}

Each value represents the average of three replicate analysis \pm S.D

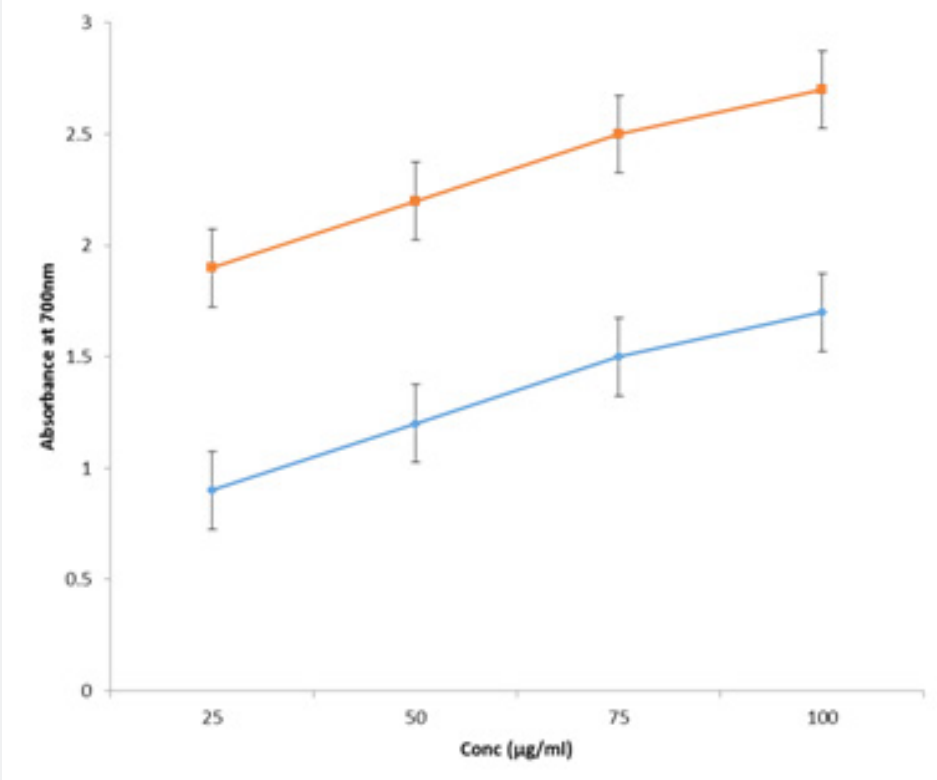

In the present study reducing power assay was performed to determine the antioxidant potential of Silybummarianum seed oil. Concentrations of 25, 50, 75 and $100 \mu \mathrm{g} / \mathrm{ml}$ were used for the analysis of antioxidant activity of both oil and standard. Reducing power ability was determined according to the absorbance of spectrophotometer. Finally the results of the assay were compared with ascorbic acid. It was used as a standard. A significant difference was found between absorbance values at different concentrations. Absorbance of Silybummarianum seed oil $(0.9,1.2,1.5,1.7)$ and ascorbic acid $(1.9,2.2,2.5,2.7)$. Results of reducing power assay are shown in Figure 2.

\section{Discussion}

\section{Proximate analysis}

Proximate analysis of Silybummarianum shows resemblance to other studies conducted on milk this tle having moisture $4.6 \%$, protein $17.64 \%$, fiber $25.32 \%$, ash $5.10 \%$ [37]. In other studies, the reported moisture, ash and protein content of Silybummarianum are $4.48 \%, 1.93 \%, 23.80 \%$. Value of crude fiber (5.48\%) shows variation due to geographical and environmental variations [20]. 
Moisture content calculated for Silybummarianum is $8.2 \%$ which shows a close resemblance with moisture content of Erucasativa (5.23\% and 4.1\%), black olive (5.77-27.77\%) and Annonamuricata (11.01\%) [38-41]. Silybummarianum shows relatively low moisture content. It is beneficial to enhance the shelf life and to reduce the pathogenic attack [42].

Protein content calculated for Silybummarianum (15.75) shows close resemblance with Sun flower (16.9-25.1\% and $20 \%)$, Eruca sativa (27.4\%), Sonchusasper (13.2\%) and Annonamuricata (25\%) content [39,41,43-45]. Protein is very important as a source of energy, precursor of enzymes, hormones, important structures and involve in defense functioning of the body [46]. Silybummarianum leaves can be considered as a good source of protein. It can be used as protein supplement to meet the need of protein.

Ash value (4\%) calculated for Silybummarianum also shows close resemblance with some other plants like $3.5 \%$ for sun flower, 6.6\% for Erucasativa, 3.50\% for Moringaoleifera and 4.76 for Catharanthusroseus [39,44,47,48].

Crude fiber calculated for Silybummarianum is $24 \%$. It is similar to the crude fiber of Annonamuricata (22.20\%) and Sonchusasper (18.3\%) [41,49]. Fibre is helpful for detoxification in the stomach and maintains cholesterol level [50]. Fat content? of Silybummarianum is very close to Erucasativa $(26 \pm 1.2 \%)$ fat content [39]. Silybummarianum dry matter content (91.8 $\%$ ) is closely resembles with Catharanthusroseus (91.94) and Annonamuricata (88.9\%) [41,51].

\section{Physicochemical parameters}

Specific gravity of Silybummarianum is 0.8129 unit?. However, in plants such as Butyrospermumparkii oil, Dacryodesedulis and Nigerian pumpkin, the specific gravity was $0.87,0.895$, and 0.830 respectively. The specific gravity of these plants show close resemblance to Silybummarianum [52].

Free fatty acid content of Silybummarianum is $2.53 \mathrm{mg} / \mathrm{g}$. This value shows similarities to Dacryodesedulis seed oil (2.782.81) [52]. Silybummarianum has a lower amount of free fatty acid. Fatty acid content depends on the soil conditions and climatic effects under which a plant is growing [53]. Fatty acids play a vital role in plant cellular activities [54].

Peroxide value of Silybummarianum (7.056 meq. Peroxide/g) is very close to peroxide value of Moringaoleifera (8.10-15.96 meq. peroxide/g) and Citrulluslanatu soil (2.90-5.06 meqO $\mathrm{kg}^{-1}$ ) [51,55]. Refined oils have low value of peroxide then the unrefined oils [56]. Milk thistle has low peroxide value which shows its low oxidation, rancidity and high antioxidant activity.

Saponification value of Silybummarianum is $126.2 \mathrm{mg} \mathrm{KOH} / \mathrm{g}$ which is very close to saponification vale of Moringaoleifera (134.3mg KOH/g) [47]. Due to high content of saponins milk thistle it is very good for the soap industry. Increase in saponification value increases quality and volatility of the oil [57].
$\mathrm{pH}$ calculated for Silybummarianum is 8.09. However, this value is 6.78 for same milk thistle and 6.6 for white variety of Silybummarianum [17,58]. Wax content calculated for Silybummarianum is in the range of study conducted by Hamid et al. [39] i.e., $17.073 \pm 0.050 \%$.

Iodine value of Silybummarianum is $2.79 \mathrm{mg} / \mathrm{g}$ which is very close to iodine value of Nigerian almond i.e., $2.65-153.00 \mathrm{~g}$ I2/100g [52]. Oil with low iodine value are resistant to oxidation due to presence of less unsaturated bonds [59]. Oils with low iodine value are nondrying oils due to their susceptibility to oxidation. So these oils are very suitable to be used in soap industry [60].

Ester value calculated for Silybummarianum is $121.15 \mathrm{mg} / \mathrm{g}$ which show resemblance with value of Chrysophyllumalibidum $(122.74 \mathrm{mg} / \mathrm{g})$ and Vignasubterrenea (123.88) [52]. Acid value of Silybummarianum is calculated to be $5.049 \mathrm{mg} \mathrm{KOH} / \mathrm{g}$ which is very close to $5.56-5.61 \mathrm{mg} \mathrm{KOH} / \mathrm{g}$ for Dacryodesedulis and5.764mg $\mathrm{NaOH} / \mathrm{g}$ for Lavandulabipinnata seed oil [52]. Plants with low acid value are highly antioxidant, edible and can be used in soap industry [59]. Milk thistle has a low acid value so it is highly antioxidant and suitable for the use in soap industry.

\section{Antioxidant analysis}

Essential oils of the plants which possess medicinal and antioxidant properties are largely studied and of great interest for their commercial purposes [61]. Reducing power gives a clear cut picture of antioxidant ability of a plant $[62,63]$. Reducing power action involves the reduction of $\mathrm{Fe}^{+3}$ ion into $\mathrm{Fe}^{+2}$ ion which results in the formation of bluish colour ferri cyanide complex at $700 \mathrm{~nm}$ [64]. It is concluded that reducing power ability increases with the increase in concentration [65]. Furthermore the results of present study can also be justified by other studies $[55,66]$.

\section{Conclusion}

Due to high content of saponin, milk thistle it is very good for the soap industry. Increase in saponification value increases quality and volatility of the oil. Milk thistle has low peroxide and acid values which show its low oxidation [67-69], rancidity and high antioxidant activity and its suitability for the use in soap industry. Reducing power of $S$. marianum increases with the increase in concentration [70-72]. Overall results indicate that Silybummarianum is good source of nutraceuticals components and also find its application in pharmaceutical industry. Silybummarianum is highly hepatoprotective as well as a good antioxidant.

\section{References}

1. Corchete P (2008) Silybummarianum (L.) Gaertn: the source of silymarin. In: Ramawat KG, Merillon JM (Eds.), Bioactive Molecules and Medicinal Plants. Springer pp. 123-148.

2. Fathi Achachlouei B, Azadmard Damirchi S (2009) Milk thistle seed oil constituents from different varieties grown in Iran. Journal of American Oil Chemistry Society 86(7): 643-649. 
3. Sidhu MC, Saini P (2011) Anatomical investigations in Silybummarianum (L.) Gaertn. Journal of Biological Research 8: 603-608.

4. Karkanis A, Bilalis D, Efthimiadou A (2011) Cultivation of milk thistle (Silybummarianum L. Gaertn.), a medicinal weed. Industrial Crops and Products 34(1): 825-830.

5. Toyang NJ, Verpoorte R (2013) A review of the medicinal potentials of plants of the genus vernonia (Asteraceae). Ethnopharmacol 146(3): 681-723.

6. Ercetin T, Senol FS, Erdogan I \& Toker G (2012) Comparative assessment of antioxidant and cholinesterase inhibitory properties of the marigold extracts from Calendula arvensis L. and Calendula officinalis L. Industrial Crops and Products 36(1): 203-208.

7. Carrubba A, Torre RL (2003) Cultivation trials of milk thistle (Silybummarianum Gaertn.) into the semiarid Mediterranean environment. Agricultural Food Sector in the Mediterranean Region 133: $14-19$

8. Barreto JFA, Wallace SN, Carrier DJ, Clausen EC (2003) Extraction of Nutraceuticals from milk thistle: Hot water extraction. Appl Biochem Biotechnol 105: 881-889.

9. Bhattacharya S (2011) Phytotherapeutic properties of milk thistle seeds: An overview. Journal of Advanced Pharmaceutical Education Research 1: 69-79.

10. Abu Rajouh KS, Takruri HR (2000) Studing the nutritional value of milk thistle seeds. Arab Journal of Food and Nutrition 2: 31-47.

11. Curioni A, Carcía W, Alfonso, Arizio O (2002) Prediction of the harvest of Cardomarian through the external characteristics presented in the chapters. Acta Horticulturae 569: 257-261.

12. Carrier DJ, Crowe T, Sokhansanj S, Wahaband J, Barl B (2003) Milk Thistle Silybummarianum (L.) Gaertn, flower head development and associated marker compound profile. Journal of Herbs Spices and Medicinal Plants 10 (1): 65-74.

13. Hadolin M, Skerget M, Knes Z, Bauman D (2001) High pressure extraction of vitamin e-rich oil from Silybummarianum. Food chemistry 74(3): 355-364.

14. Shaker E, H Mahmoud, Mnaa S (2010) Silymarine, the antioxidant component and Silybummarianum extract prevent liver damage. Food and Chem Toxicol 48(3): 803-806.

15. Jacobs BP, Dennehy C, Ramirez G, Lawrence VA (2002) Milk thistle for the treatment of liver disease: A systematic review and meta-analysis. Am J Med 113(6): 506-515.

16. Lovkova M, Rabinovich AM, Ponomareva SM, Buzuk GN, Sokolova SM (1989) Why plants cure, Nauka, Moscow, p. 202.

17. Malekzadeh M, Mirmazloum IS, Anguorani HR, Mortazavi SN, Panahi M (2011) The physicochemical properties and oil constituents of milk thistle (Silybummarianum Gaertn. cv. Budakalaszi) under drought stress. Journal of Medicinal Plants Research, 5(8): 1485-1488.

18. El Mallah MH, El-Shami SM, Hassanein MM (2003) Detailed studies on some lipids of Silybummarianum (L.) seed oil. Grasas Aceites 54(4): 397-402.

19. Gresta F, Avola G, Guarnaccia P (2006) Agronomic characterization of some spontaneous genotypes of milk thistle (Silybummarianum L. Gaertn.) in mediterranean environment. Journal of Herbs, Spices and Medicinal Plants 12(4): 51-60.

20. Khan I, Khattak HU, Ullah I, Bangash FK (2007) Journal of Chemical Society of Pakistan 29(6).

21. Polyak SJ, Morishima C, Lohmann, Pal S, Lee DYW, et al. (2010) Identification of hepatoprotective flavonolignans from silymarin. Proc Natl Acad Sci USA 107(13): 5995-5999.
22. Zarrelli A, Romanucci V, Greca MD, Napoli LD, Previtera L, Fabio GD (2013) New silybin scaffold for chemical diversification: Synthesis of novel 23-phosphodiester silybin conjugates. Journal Information Synlett 24(1): 45-48.

23. Jancova P, Siller M, Anzenbacherova E, Kren V, Anzenbacher P, et al (2011) Evidence for differences in regioselective and stereoselective glucuronidation of silybin diastereomers from milk thistle (Silybummarianum) by human UDP-glucuronosyltransferases. Xenobiotica 41(9): 743-751.

24. Karabulut I, Kayahan M, Yapark S (2003) Determination of changes in some physical and chemical properties of soybean oil during hydrogenation. Food Chemistry 81(3): 453-456.

25. Nyiredy S, Szucs Z, Antus S, Samu Z (2008) New components from Silybummarianum L. Fruits: A theory comes true. Chromatographia 68: 5-11.

26. Abenavoli L, Capasso R, Milic N, Capasso F (2010) Milk thistle in liver diseases: past, present, future. Phytother Res 24(10): 1423-1432.

27. Din M, Naila C, Sarzamin K, Asad S, Mohammad M et al. (2012) Hepatoprotective role of milk thistle (silybummarianum) in meat type chicken fed aflatoxin B1 contaminated feed. Pakistan Veterinary Journal 32(3).

28. Huseini HF, Larijani B, Heshmat R, Fakhrzadeh H, Radjapour B, et al. (2006) The Efficacy of Silybummarianum (L.) in the treatment of type ii diabetes: a randomized, double-blind, placebo-controlled, clinical trial. Phytotherapy Research 20(12): 1036-1039.

29. Sagar SM (2007) Future directions for research on Silybummarianum for cancer patients. Integr Cancer Ther 6(2): 166-173.

30. Ramasamy K, Agarwal R (2008) Multitargeted therapy of cancer by silymarin. Cancer Lett 269(2): 352-362.

31. Toklu HZ, Akbay TT, Ogunc AV, Ercan F, Gedik N, et al. (2008) Silymarin, the antioxidant component of silybummarianum prevents sepsis induced acute lung and brain injury. J Surg Res 145(2): 214-222.

32. Quan L, Li SF, Tian SJ, Xu H, Lin AQ et al. (2004) Determination of organ chlorine pesticides residue in ginseng root by orthogonal array design soxhlet extraction and gas chromatography. Chromatographia 1(1-2): 89-93.

33. Association of Official Analytical chemists (AOAC) (1990) Official Methods of Analysis, ( $15^{\text {th }}$ edn). Association of Official Analytical Chemists. Arlington, Virginia, USA.

34. Gohari AR, Seyed NO, Moradi Afrapoli F, Malmir M, Tavajohi S, et al. (2011) Evaluation of cytoxicity of Saturejaspicigera and its main compounds. Scientific World Journal.

35. Okpuzor J, Okochi VI, Ogbungafor HA, Ogbonnia S, Fagbayi T et al. (2009) Estimation of cholesterol level in different brands of vegetable oils. Pakistan Journal of Nutrition 8: 57-62.

36. Chung YC, Chang CT, Chao WW, Lin CF, Chou ST, et al. (2005) Study on antioxidant activity of Graptopetalum paraguayense E Walther. Food Chemistry 91(3): 419-424.

37. Dabbour RI, Al-Ismail KM, Takruri HR, Azzeh FS (2014) Chemical Characteristics and Antioxidant Content Properties of Cold Pressed Seed Oil of Wild Milk Thistle Plant Grown in Jordan. Pakistan Journal of Nutrition 13(2): 67-78.

38. Sharma V, Garg G, Alam A (2014) Extraction and characterization of industrially valueable oil from Eruca sativa $(L$.) Mill through FT-IR and GC-MS analysis. American Journal of Biological Chemistry 2(4): 23-28.

39. Hamid S, Sahar A, Malik F, Hussain S, Mahmood R, et al. (2014) Physicochemical investigation and antioxidant activity studies on extracts of Eruca sativa seed. International Journal of Pharmaceutical Chemistry $4(4)$. 
40. Nyam AM, Makut MD, telima I, Daniel AM (2014) Nutritional potential of the fruit of the black olive (Canariumschweinfurthii Linn) from Plateau State, Nigeria. Pakistan Journal of Nutrition 13(6): 335-339.

41. Usunobun U (2014) Antihepatotoxic efficacy of Vernoniaamygdalinaethanolic leaf extract on Dimethylnitrosamine (DMN)- induced liver damage in rats. International Journal of Healthcare and Biomedical Research 3(1): 89-98.

42. Ruberto G, Baratta MT (2000) Antioxidant activity of selected essential oil components in two lipid model systems. Food Chemistry 69(2): 167-174.

43. Roberston JA, Thomas JK, Burdick D (1971) Chemical composition of the seed of sunflower hybrids and open pollinated varieties. Journal of Food Science 36(6): 873-876.

44. Dreher ML, Roath WW, Holm ET, Appolonia BD (1983) Yield, characteristics and composition of oil-type hybrid sunflower seed grown in north Dakota. Journal of American Oil Chemist's Society, p. 60.

45. Jimoh OF, dedapo AA, Afolayan AJ (2011) Comparison of the nutritive value, antioxidant and antibacterial activities of Sonchusasper and Sonchusoleraceus. Records of Natural Products 5: 1 .

46. Bailey R (2008) The Role of Proteins in the Body. About com Guide to Biology.

47. Goja MA (2013) Physico-chemical properties of oil produced from Moringaoleifera, Jatrophacurcas and Carthamustinctorius $L$ seeds. International Journal of Advanced Research 1(4): 181-187.

48. Esther EA, Maureen CO, Ruffina AN, Ann MO, Chisom IF, et al. (2016) Preliminary studies on the phytochemical and proximate compostion Catharanthusroseus (Linn). International Journal of Botany Studies, 1(3): 08-10.

49. Jimoh WA, Aroyehun HT (2011) Evaluation of cooked and mechanically defatted sesame (Sesamumindicum) seed meal as a replacer for soybean meal in the diet of African catfish (Clariasgariepinus). Turkish Journal of Fisheries and Aquatic Sciences 11: 185-190.

50. Mensah JK, Okoli RI, Ohaju-Obodo JO, Eifediyi K (2008) Phytochemical, nutritional and medical properties of some leafy vegetables consumed by Edo people of Nigeria. African Journal of Biotechnology 7(14): 2304-2309.

51. Grzeszczuk M, Wilas J, Walejko A, Sitarz E (2013) Contenta of biological active compounds in water extraction of Periwinkle (Catharanthusroseus (L.) G. DON). Journal of International Scientific Publications: Agriculture and Food, 2.

52. Aremu OMH, Ibrahim, Bamidele TO (2015) Physicochemical Characteristics of the Oils Extracted from Some Nigerian Plant Foods -A Review. Chemical and process engineering research, p. 32.

53. Beckman CH (2000) Phenolic-storing cells: keys to programmed cell death and periderm formation in wilt disease resistance and in general defense responses in plants. Physiological and Molecular Plant Pathology 57(3): 101-110.

54. Mander L, Liu HW (2010) Comprehensive Natural Products II. Chemistry and Biology 1: 5-28.

55. Rafiee Z, Jafari S, Alami M, Khomeiri M (2012) Antioxidant effect of microwave-assisted extract of olive leave on sunflower oil. J Agr Sci Tech 14:1497-1509.
56. Kyari MZ (2008) Extraction and characterization of seed oils. International Agrophysics 22: 139-142.

57. Engler CR, Johnson LA (1983) Effects of processing and chemical characteristics of plant oils on performance of an indirect-injection diesel engine. Journal of American Oil Chemical Society 60(8): 1592 -1596 .

58. Ottai MES, Abdel-Moniem ASH (2006) Genetic Parameter Variations Among Milk Thistle, Silybummarianum Varieties and Varietal Sensitivity to Infestation with Seed-head Weevil, Larinuslatus Herbst. Internal Journal of Agriculture and Biology 8: 862-866.

59. Aremu MO, Olaofe O, Akintayo ET (2006) Chemical composition and physicochemical characteristics of two varieties of bambara groundnut (Vignasubterrenea) flours. Journal of Applied Sciences 6(9): 19001903.

60. Kochhar SL (1998) Economic Botany in the Tropics. In: $\left(2^{\text {nd }}\right.$ edn), Macmillan India Ltd, India, pp. 354-355.

61. Parejo I, Viladomat F, Bastida J, Rosas-Romero J, Flerlage A, et al. (2002) Comparison between the radical scavenging activity and antioxidant activity of six distilled and non distilled Mediterranean herbs and aromatic plants. Journ Agric Food Chem 50(23): 6882-6890.

62. Chang, LW, Yen WJ, Huang SC, Duh PD (2002) Antioxidant activity of sesame coat. Food Chemistry 78(3): 347-354.

63. Yen GC, Duh PD (1993) Antioxidative properties of methanolic extracts from peanut hulls. Journal of the American Oil Chemistry Society 70(4): 383-386.

64. Arulpriya P, Lalitha P, Hemalatha S (2010) Invitro antioxidant testing of the extract of Samaneasaman. Der Chemica Sinica 1(2): 73-79.

65. Ayesha NJ, Rahman KU, Nosheen S (2013) Gemmo modification: An emerging source of natural antioxidants from Silybummarianum. Pakistan Journal of Pharmaceutical Sciences 26(3): 585-591.

66. Abdel-Hameed SE, Bazaid SA, Sabra ANA (2013) Protective effect of Conocarpus erectus extract on CCL 4-induced injury in mice. Global Journal of Pharmacology 7(1): 52-60.

67. Alemardan A, Karkanis A, Salehi R (2013) Breeding Objectives and Selection Criteria for Milk Thistle [Silybummarianum (L.) Gaertn.] Improvement. Notulae Botanicae Horti Agrobotanici 41(2): 340-347.

68. Hanafi ME, Hegazy EM, Riad RM, Amer HA (2010) Bio protective effect of Eruca sativa seed oil against the hazardus effect of aflatoxin B1 in male rabbits. International Journal of Academic Research, 2.

69. Herborn JB (1998) Phytochemical Methods: A Guide to Modern Techniques of Plant Analysis. In: ( $2^{\text {nd }}$ edn), Hall, New York, USA, pp. 5-11.

70. Hermenean A, Stan M, Ardelean A, Pilat L, Mihali CV, et al. (2015) Antioxidant and hepatoprotective activity of Milk Thistle seed oil. Open life sciences 10(1): 147-158.

71. Khan MZ, Blackshaw RE, Marwat KB (2009) Biology of milk thistle (Silybummarianum) and the management options for growers in north-Pakistan. Weed Biology Management 9(2): 99-105.

72. Lemos TLG, Matos FJA, Alencar JW, Crareiro AA, Clark AM, et al. (1990) Antimicrobial activity of essential oils of Brazilian plants. Phytoptherapy Research 4(2): 82-84.

73. Lovkova M, rabinovich AM, ponomareva SM, Buzuk GN, sokolova SM, et 


Your next submission with Juniper Publishers
will reach you the below assets
- Quality Editorial service
- Swift Peer Review
- Reprints availability
- E-prints Service
- Manuscript Podcast for convenient understanding
- Global attainment for your research
- Manuscript accessibility in different formats
( Pdf, E-pub, Full Text, Audio)
- Unceasing customer service
Track the below URL for one-step submission
https://juniperpublishers.com/online-submission.php

